\title{
IMPLEMENTASI KURIKULUM 2013 DALAM PEMBELAJARAN PRAKTIK PEMELIHARAAN SASIS DAN PEMINDAH TENAGA KENDARAAN RINGAN DI SMK MUHAMMADIYAH 1 BANTUL
}

\author{
Yunanto Hanif Hidayah \\ SMK PIRI I Yogyakarta \\ Email: yunantohanifh@gmail.com
}

\begin{abstract}
This study aims to find out: (1) the implementation of 2013 curriculum in PSPTKR practice planning at Muhammadiyah 1 Bantul Vocational School, (2) the implementation of 2013 curriculum in learning activity of PSPTKR practice at Muhammadiyah 1 Bantul Vocational School, (3) and the 2013 curriculum implementation in learning assessment of PSPTKR practice at Muhammadiyah 1 Bantul Vocational School. This study involved 5 PSPTKR subject teachers and all TKR XI grade students as research subjects. Data taken by questionnaires and interviews. Conclusions obtained from the results of two methods and interpreted according to the indicator criteria. The results showed that the implementation of the 2013 Curriculum on aspects of learning planning was included in the fully implemented category with a percentage of $86.35 \%$. However, there are still weaknesess in the implementation of the 2013 curriculum because teachers have not been maximal in applying the RPP principles. In the aspect of learning implementation, the implementation of the 2013 curriculum was included in the fully implemented category with a percentage of $86.92 \%$, but there were still weaknesses in teacher interactions that were less supportive of student activity and active participation. In the aspect of learning assessment, the implementation of the 2013 Curriculum was included in the fully implemented category with a percentage of $81.43 \%$. However, there are still weaknesses in implementing learning assessment because the teacher has not been maximal in using a variety of assessment methods.
\end{abstract}

Keywords: implementation, 2013 curriculum, planning, implementation, and assessment of learning.

\begin{abstract}
Abstrak
Penelitian ini bertujuan untuk mengetahui: (1) implementasi kurikulum 2013 dalam perencanaan pembelajaran praktik PSPTKR di SMK Muhammadiyah 1 Bantul, (2) implementasi kurikulum 2013 dalam pelaksanaan pembelajaran praktik PSPTKR di SMK Muhammadiyah 1 Bantul, (3) dan implementasi kurikulum 2013 dalam penilaian pembelajaran praktik PSPTKR di SMK Muhammadiyah 1 Bantul. Penelitian ini melibatkan 5 guru mata pelajaran PSPTKR dan seluruh siswa kelas XI TKR sebagai subjek penelitian. Pengambilan data penelitian dilakukan melalui angket dan wawancara. Kesimpulan diperoleh dari data hasil kedua metode dan diinterpretasikan sesuai dengan kriteria indikator. Hasil penelitian menunjukkan bahwa implementasi Kurikulum 2013 pada aspek perencanaan pembelajaran masuk dalam kategori sepenuhnya terlaksana dengan persentase $86,35 \%$. Namun, masih terdapat ketidakoptimalan dalam implementasi kurikulum 2013 dikarenakan guru belum maksimal dalam menerapkan prinsip-prinsip penyusunan RPP. Pada aspek pelaksanaan pembelajaran, implementasi kurikulum 2013 masuk dalam kategori sepenuhnya terlaksana dengan persentase $86,92 \%$, akan tetapi masih terdapat ketidakoptimalan pada interaksi guru yang kurang mendukung keaktifan dan partisipasi aktif siswa. Pada aspek penilaian pembelajaran, implementasi Kurikulum 2013 masuk dalam kategori sepenuhnya terlaksana dengan persentase $81,43 \%$. Namun, dalam mengimplementasikan penilaian pembelajaran masih terdapat kelemahan dikarenakan guru belum maksimal dalam menggunakan variasi metode penilaian.
\end{abstract}

Kata kunci: implementasi, kurikulum 2013, perencanaan, pelaksanaan, dan penilaian pembelajaran. 


\section{PENDAHULUAN}

Pendidikan adalah rekonstruksi atau reorganisasi pengalaman yang menambah makna pengalaman, dan yang menambah kemampuan untuk mengarahkan pengalaman selanjutnya (Dewey dalam Siswoyo 2013: 47). Pendidikan merupakan usaha untuk pembinaan kepribadian dan kemajuan manusia baik jasmani maupun rohani. Dalam kehidupan berbangsa dan bernegara, pendidikan diperlukan untuk meningkatkan sumber daya manusia (SDM) suatu bangsa, karena sumber daya manusia (SDM) suatu bangsa menentukan kemajuan bangsa tersebut.

Setiap bangsa terus melakukan upaya agar kualitas pendidikan senantiasa meningkat sehingga dapat bersaing secara global. Upaya yang dilakukan yaitu dengan mengubah komponen-komponen yang mempengaruhi sistem pendidikan itu sendiri. Salah satunya adalah Perubahan kurikulum bertujuan agar sistem pendidikan berjalan sesuai dengan kebutuhan dan perkembangan zaman.

Undang-undang No 20 tahun 2003 tentang Sistem Pendidikan Nasional menjelaskan bahwa kurikulum adalah seperangkat rencana dan pengaturan mengenai tujuan, isi, dan bahan pelajaran serta cara yang digunakan sebagai pedoman penyelenggaraan kegiatan pembelajaran untuk mencapai tujuan pendidikan tertentu. Selaras dengan pendapat Daryanto (2014: 1) bahwa kurikulum adalah rancangan pendidikan yang memberi kesempatan untuk peserta didik mengembangkan potensi dirinya dalam suatu suasana belajar yang menyenangkan dan sesuai dengan kemampuan dirinya untuk memiliki kualitas yang diinginkan masyarakat dan bangsanya. Berdasarkan uraian di atas, dapat ditarik kesimpulan bahwa kurikulum merupakan seperangkat rancangan sistem pendidikan yang utuh yang sesuai dengan tujuan pendidikan.

Kurikulum 2013 merupakan kurikulum pembaruan yang mulai diberlakukan sejak tahun 2013 sebagai pengganti kurikulum tingkat satuan pendidikan (KTSP). Pembaruan pada kurikulum 2013 tercantum dalam Permendikbud Nomor 22 Tahun 2016 antara lain: kurikulum 2013 menekankan pada peningkatan dan keseimbangan antara keterampilan mental (soft skills) dan keterampilan fisikal (hard skills) yang meliputi aspek kompetensi sikap, pengetahuan, dan keterampilan, menekankan peserta didik untuk aktif mencari tahu (student oriented), serta pembelajaran yang berbasis kompetensi. Pembaharuan pembelajaran dalam kurikulum 2013 juga terletak pada pembelajaran yang menekankan pada dimensi pedagogik modern dengan berbagai model pembelajaran maupun pendekatan yang berbasis ilmiah (scientific learning).

Adanya pembaruan tersebut, menuntut guru untuk memahami kurikulum 2013 secara lebih mendalam dan menyeluruh mengingat guru menjadi ujung tombak dalam proses penerapannya. Kompetensi guru, khususnya guru otomotif yang masih kurang dalam kompetensi professional, pedagogik, social, dan kepribadian perlu untuk ditingkatkan (Yuswono, Martubi, Sukswanto, \& Budiman, 2015). Apapun model, strategi, metode atau media pembelajaran yang digunakan, pendekatan ilmiah (scientific learning) harus diterapkan. Guru harus merencanakan prosedur pembelajaran sesuai dengan model pembelajaran yang merujuk pada pendekatan ilmiah (Sofyan, Arifin, \& Tafakur, 2017: 331). Terlebih lagi, dalam kurikulum 2013 peran guru lebih bersifat sebagai penyedia pengalaman belajar (fasilitator). Guru tidak lagi diposisikan sebagai satu-satunya sumber belajar, tetapi 
hanya sebagai salah satu dari semua sumber belajar yang bisa digunakan oleh siswa (As'ari, 2014: 6), dengan begitu seyogyanya guru mampu menciptakan pengalaman belajar yang dapat mendorong partisipasi aktif siswa. Begitu pula dengan siswa juga harus mempunyai tanggapan yang baik terhadap pembelajaran. Guru dan murid merupakan pemeran utama dalam penerapan kurikulum 2013 sehingga tanggapan guru dan murid menjadi salah satu poin yang perlu diperhatikan supaya kurikulum 2013 mampu menjalankan perannya dengan baik.

SMK Muhammadiyah 1 Bantul adalah salah satu SMK di Kabupaten Bantul yang telah menerapkan kurikulum 2013 dalam pembelajarannya. Namun demikian, kesadaran siswa untuk belajar terhadap suatu mata pelajaran di SMK Muhammadiyah 1 Bantul masih kurang. Hal ini terlihat pada saat dilakukan observasi pembelajaran pada bulan November 2017 di kelas XI TKR pada mata pelajaran Pemeliharaan Sasis dan Pemindah Tenaga Kendaraan Ringan (PSPTKR), dimana saat pembelajaran berlangsung siswa cenderung kurang aktif, siswa lebih sering bermain handphone atau mengobrol dengan teman lain apabila tidak diawasi. Selain itu, siswa lebih sering mendahulukan bertanya sebelum membaca jobsheet, sedangkan prosedur praktik PSPTKR sudah dijelaskan pada jobsheet. Hal ini menunjukkan sebagian siswa belum memiliki kesadaran belajar yang tinggi, sehingga mengakibatkan kompetensi tidak tercapai. Hal ini dibuktikan saat pelaksanaan ujian praktik PSPTKR kelas XI TKR tahun ajaran 2017/2018, banyak siswa masih kebingungan ketika diminta untuk menyebutkan nama-nama komponen transmisi dan sistem rem, begitu pula saat siswa diminta untuk merakit komponen transmisi dan komponen rem, masih banyak siswa yang mengalami kesulitan, sehingga salah dalam pemasangan. Selain itu, Ketua Kompetensi Keahlian TKR, menyatakan bahwa dalam pembelajaran, konsep student centered belum bisa diterapkan secara optimal terhadap siswa karena siswa kurang kooperatif. Sejauh ini, pembelajaran tidak sepenuhnya menggunakan kurikulum 2013. Pelaksanaan kurikulum 2013 dalam pembelajaran masih sebatas pada kompetensi inti dan kompetensi dasar yang memungkinkan untuk diterapkannya kurikulum tersebut. Berdasarkan kondisi di atas, maka diperlukan adanya studi untuk mengetahui seberapa jauh implementasi Kurikulum 2013 khususnya pada pembelajaran praktik Pemeliharaan Sasis dan Pemindah Tenaga Kendaraan Ringan (PSPTKR) di SMK Muhammadiyah 1 Bantul.

\section{METODE PENELITIAN}

\section{Jenis Penelitian}

Penelitian ini merupakan penelitian deskriptif (descriptive research) yang bertujuan untuk mendeskripsikan atau menggambarkan fenomena-fenomena yang ada, baik fenomena yang bersifat alamiah ataupun rekayasa manusia (Sukmadinata, 2013: 72), dalam hal ini adalah implementasi Kurikulum 2013 dalam pembelajaran praktik PSPTKR di SMK Muhammadiyah 1 Bantul meliputi aspek perencanaan, pelaksanaan, dan penilaian pembelajaran. 


\section{Waktu dan Tempat Penelitian}

Observasi pra penelitian dilaksanakan pada bulan Agustus-September 2018 bertempat di SMK Muhammadiyah 1 Bantul. Penyusunan instrumen dilakukan pada bulan Desember 2018 di kampus FT UNY. Penelitian dan analisis tanggapan guru dan siswa dilaksanakan pada bulan Februari 2019 di SMK Muhammadiyah 1 Bantul.

\section{Objek dan Subjek Penelitian}

Objek dalam penelitian ini adalah implementasi kurikulum 2013 dalam pembelajaran praktik PSPTKR. Subjek dalam penelitian ini terdiri dari guru dan siswa. Guru pengampu mata pelajaran PSPTKR sebanyak 5 orang, dan siswa kelas XI Teknik Kendaraan Ringan (TKR) sebanyak 123 orang. Penelitian ini menggunakan studi populasi yaitu mempelajari seluruh subjek secara langsung (Azwar, 2010: 35).

\section{Prosedur}

Penelitian ini merupakan penelitian deskriptif (descriptive research) yang bertujuan untuk mendeskripsikan implementasi Kurikulum 2013 dalam pembelajaran praktik PSPTKR di SMK Muhammadiyah 1 Bantul meliputi aspek perencanaan, pelaksanaan, dan penilaian pembelajaran. Tahap awal penelitian, yaitu menganalisis permasalahan berdasarkan observasi pra penelitian di SMK Muhammadiyah 1 Bantul. Tahap selanjutnya adalah analisis penggunaan metode penelitian dan penyusunan instrumen. Data dalam penelitian ini diperoleh melalui instrumen angket dan wawancara. Angket (kuesioner) ditujukan untuk siswa dan guru, sedangkan wawancara ditujukan untuk guru guna memperoleh informasi yang tidak dapat diungkap melalui kuesioner.

\section{Data, Intrumen, dan Teknik Pengumpulan Data}

Data dalam penelitian ini terdiri dari data kuantitatif dan kualitatif. Data kuantitatif berupa hasil pengubahan penilaian oleh guru dan siswa menjadi bentuk persentase sedangkan data kualitatif berupa jawaban dan tanggapan dari guru. Data-data ini digunakan sebagai acuan dalam menentukan keterlaksanaan Kurikulum 2013 dalam pembelajaran praktik PSPTKR.

Instrumen yang digunakan dalam penelitian ini yaitu instrumen angket guru, instrumen angket siswa dan pedoman wawancara guru. Angket ditujukan kepada guru selaku pelaksana Kurikulum 2013 dan kepada siswa selaku penerima Kurikulum 2013 dalam bentuk pembelajaran, serta wawancara kepada guru yang dilakukan untuk memperoleh informasi yang tidak dapat diperoleh melalui angket. Teknik pengumpulan data dilakukan dengan metode wawancara dan kuesioner.

\section{Teknik Analisis Data}

Bagaimana memaknakan data yang diperoleh, kaitannya dengan permasalahan dan tujuan penelitian, perlu dijabarkan dangan jelas.

Data-data yang diperoleh dalam penelitian ini akan dianalisis sesuai dengan jenisnya. Data berupa tanggapan yang diperoleh dari hasil wawancara dengan guru akan dianalisis secara deskriptif. Data berupa skor penilaian akan dianalisis melalui pengubahan hasil penilaian menjadi bentuk kuantitatif yang didasarkan pada skor yang diperoleh dari jumlah 
skor tiap kelompok butir pertanyaan. Skor masing-masing butir pernyataan berada pada rentang 4 sampai 1 sesuai Tabel 1 berikut:

Tabel 1. Teknik Penskoran Angket Guru dan Siswa.

\begin{tabular}{|l|c|}
\hline \multicolumn{1}{|c|}{ Kategori } & Skor \\
\hline Sepenuhnya Terlaksana & 4 \\
\hline Sebagian Besar Terlaksana & 3 \\
\hline Sebagian Kecil Terlaksana & 2 \\
\hline Belum Terlaksana & 1 \\
\hline
\end{tabular}

Persentase skor penilaian diperoleh dengan membandingkan skor dalam kenyataan dengan skor harapan, kemudian dirumuskan dengan rumus analisis deskriptif persentase (Arikunto, 2013: 209), sebagai berikut:

$$
\left(D P=\frac{n}{N} \times 100 \%\right)
$$

dengan:

$$
\begin{array}{ll}
D P & =\text { deskriptif persentase } \\
n & =\text { jumlah skor yang diperoleh } \\
N & =\text { jumlah skor ideal }
\end{array}
$$

Selanjutnya, persentase tiap aspek akan ditafsirkan sesuai kategori yang ada. Menurut Riduan (2013: 83-95), untuk menentukan tingkat kategori, digunakanlah cara sebagai berikut:

Menentukan persentase tertinggi

$$
\begin{gathered}
\left(\frac{\text { Skor maksimal }}{\text { skor maksimal }} \times 100 \%\right) \\
\frac{4}{4} \times 100 \%=100 \%
\end{gathered}
$$

Menentukan angka persentase terendah

$$
\begin{gathered}
\left(\frac{\text { Skor minimal }}{\text { skor maksimal }} \times 100 \%\right) \\
\frac{1}{4} \times 100 \%=25 \%
\end{gathered}
$$


Kecenderungan penilaian oleh guru dan siswa terhadap aspek-aspek pembelajaran akan dinyatakan dalam kategori yang didasarkan pada acuan pada Tabel 2 berikut:

Tabel 2. Kategori Skor untuk Angket Tentang Pembelajaran

\begin{tabular}{|c|l|}
\hline $\begin{array}{c}\text { Rentang } \\
\text { Persentase (\%) }\end{array}$ & \multicolumn{1}{c|}{ Kategori } \\
\hline $76-100$ & Sepenuhnya Terlaksana \\
\hline $51-75$ & Sebagian Besar Terlaksana \\
\hline $26-50$ & Sebagian Kecil Terlaksana \\
\hline $0-25$ & Belum Terlaksana \\
\hline
\end{tabular}

\section{HASIL PENELITIAN DAN PEMBAHASAN}

Hasil penelitian yang akan dipaparkan pada bagian ini meliputi tiga aspek yaitu persiapan pembelajaran, pelaksanaan pembelajaran, dan penilaian pembelajaran. Data yang diperoleh dalam penelitian ini merupakan data yang diperoleh melalui teknik pengumpulan data berupa angket dan wawancara. Terkait dengan hal tersebut, angket merupakan data primer yang paling utama kegiatan analisis data sedangkan hasil wawancara merupakan data pendukung yang peneliti gunakan selama penelitian di lapangan serta untuk mendeskripsikan kondisi subjek dan objek penelitian. Instrumen penelitian tersebut ditujukan kepada guru pengampu mata pelajaran PSPTKR dan siswa kelas XI TKR.

Data dianalisis berdasarkan implementasi Kurikulum 2013 terhadap beberapa aspek dalam perencanaan pembelajaran, yaitu mengenai penyusunan RPP oleh guru yang telah mengacu pada rambu-rambu silabus yang dibuat oleh pemerintah, keterkaitan antara kompetensi dasar, materi pembelajaran, kegiatan pembelajaran, indikator pencapaian kompetensi, penilaian, sumber belajar, penerapan teknologi informasi dan komunikasi, serta keterkaitan jobsheet dengan RPP yang dirancang dalam satu keutuhan pembelajaran. Data mengenai implementasi Kurikulum 2013 dalam perencanaan pembelajaran praktik PSPTKR diperoleh melalui angket yang terdiri dari 26 butir soal yang ditujukan kepada guru pengampu mata pelajaran PSPTKR yang berjumlah 5 guru. Hasil pengambilan data tersebut dapat dilihat pada Tabel 3 berikut:

Tabel 3. Hasil Penilaian Aspek Perencanaan Pembelajaran oleh Guru

\begin{tabular}{|c|c|c|}
\hline Indikator & Persentase & Kriteria \\
\hline $\begin{array}{c}\text { Penyusunan } \\
\text { Silabus }\end{array}$ & $85,00 \%$ & $\begin{array}{c}\text { Sepenuhnya } \\
\text { Terlaksana }\end{array}$ \\
\hline $\begin{array}{c}\text { Penyusunan } \\
\text { RPP }\end{array}$ & $85,28 \%$ & $\begin{array}{c}\text { Sepenuhnya } \\
\text { Terlaksana }\end{array}$ \\
\hline $\begin{array}{c}\text { Penyusunan } \\
\text { Jobsheet }\end{array}$ & $91,00 \%$ & $\begin{array}{c}\text { Sepenuhnya } \\
\text { Terlaksana }\end{array}$ \\
\hline $\begin{array}{c}\text { Rata-rata } \\
\text { Persentase }\end{array}$ & $\mathbf{8 6 , 3 5 \%}$ & $\begin{array}{c}\text { Sepenuhnya } \\
\text { Terlaksana }\end{array}$ \\
\hline
\end{tabular}


Hasil penilaian terhadap perencanaan pembelajaran oleh guru menunjukan bahwa: (1) implementasi Kurikulum 2013 penyusunan silabus oleh guru masuk dalam kriteria sepenuhnya terlaksana (75\%-100\%) dengan persentase implementasi sebesar 85,00\%. (2) Implementasi Kurikulum 2013 dalam menyusun RPP (Rencana Pelaksanaan Pembelajaran) oleh guru masuk dalam kriteria sepenuhnya terlaksana (75\%-100\%) dengan persentase 85,28\%. (3) Implementasi Kurikulum 2013 dalam menyusun Jobsheet oleh guru masuk dalam kriteria sepenuhnya terlaksana $(51 \%$ - 75\%) dengan persentase 91,00\%. Hasil penilaian pada aspek perencanaan pembelajaran, apabila disajikan dalam grafik dapat dilihat pada gambar 1 berikut:

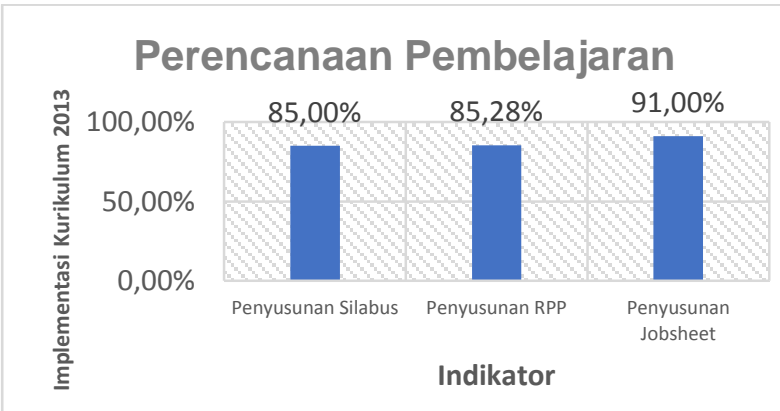

Gambar 1. Diagram batang hasil penilaian implementasi Kurikulum 2013 dalam perencanaan pembelajaran praktik PSPTKR oleh guru.

Hasil penilaian perencanaan pembelajaran di atas menunjukkan bahwa implementasi Kurikulum 2013 sepenuhnya terlaksana, akan tetapi masih terdapat kelemahan dalam implementasi Kurikulum 2013 yaitu (1) Tidak maksimalnya penyusunan RPP yang memperhatikan tingkat intelektual siswa, potensi siswa, gaya belajar siswa, kecepatan belajar siswa, perkembangan inspirasi, motivasi, kreativitas, dan minat siswa. (2) Tidak menerapkan penggunaan sumber bacaan yang terbaru sebagai referensi. Berdasarkan wawancara guru tidak menentukan buku acuan pokok bagi siswa. Guru tidak mewajibkan siswa memiliki minimal satu buku referensi akan tetapi mempersilakan siswa memilih bukunya sendiri.

Pelaksanaan pembelajaran merupakan tindak lanjut dari perencanaan pembelajaran yang sebelumnya telah dibuat oleh guru. Pelaksanaan pembelajaran dalam hal ini mencakup kegiatan pendahuluan, kegiatan inti, dan kegiatan penutup. Pengambilan data dalam bagian ini melibatkan dua pihak responden yaitu guru dan siswa kelas XI TKR. penilaian aspek pelaksanaan pembelajaran ini, diperoleh gambaran pelaksanaan pembelajaran dilihat dari segi guru selaku pelaksana dan pengatur jalannya pembelajaran. Hasil yang diperoleh dari pengambilan data mengenai pelaksanaan pembelajaran, dapat dilihat pada Tabel 4 berikut:

Tabel 4. Hasil Penilaian Aspek Pelaksanaan Pembelajaran oleh Guru

\begin{tabular}{|c|c|c|}
\hline Indikator & Persentase & Kriteria \\
\hline $\begin{array}{c}\text { Kegiatan } \\
\text { Pedahuluan }\end{array}$ & $92,00 \%$ & $\begin{array}{c}\text { Sepenuhnya } \\
\text { Terlaksana }\end{array}$ \\
\hline Kegiatan Inti & $81,67 \%$ & $\begin{array}{c}\text { Sepenuhnya } \\
\text { Terlaksana }\end{array}$ \\
\hline Kegiatan & $82,50 \%$ & Sepenuhnya \\
\hline
\end{tabular}




\begin{tabular}{|c|c|c|}
\hline Penutup & & Terlaksana \\
\hline $\begin{array}{c}\text { Rata-rata } \\
\text { Persentase }\end{array}$ & $\mathbf{8 5 , 3 3 \%}$ & $\begin{array}{c}\text { Sepenuhnya } \\
\text { Terlaksana }\end{array}$ \\
\hline
\end{tabular}

Hasil penilaian pada aspek pelaksanaan pembelajaran oleh guru, apabila disajikan dalam grafik dapat dilihat pada gambar 2 berikut:

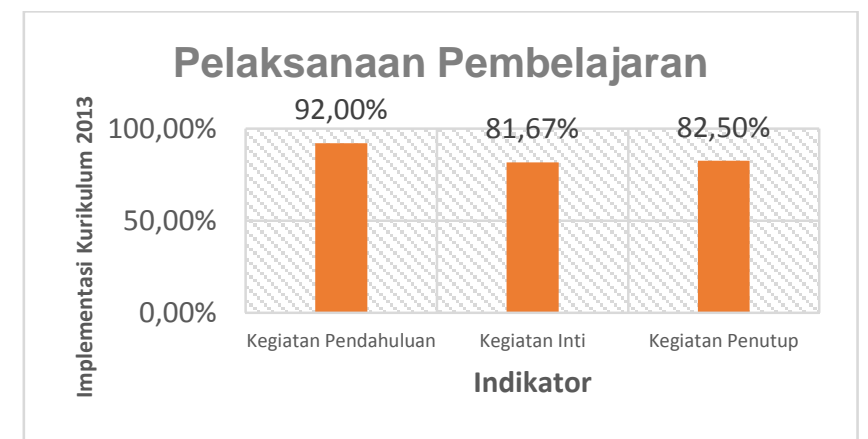

Gambar 2. Diagram batang hasil penilaian implementasi Kurikulum 2013 dalam pelaksanaan pembelajaran praktik PSPTKR oleh guru.

Hasil penilaian pelaksanaan pembelajaran oleh guru menunjukkan bahwa (1) implementasi Kurikulum 2013 dalam kegiatan pendahuluan pembelajaran yang dilaksanakan oleh guru masuk dalam kriteria sepenuhnya terlaksana (75\%-100\%) dengan persentase implementasi sebesar 92,00 \%. (2) Implementasi Kurikulum 2013 dalam kegiatan inti pembelajaran yang dilaksanakan oleh guru masuk dalam kriteria sepenuhnya terlaksana (75\%-100\%) dengan persentase implementasi sebesar 81,67\%. (3) Implementasi Kurikulum 2013 dalam kegiatan penutup pembelajaran yang dilaksanakan oleh guru masuk dalam kriteria sepenuhnya terlaksana (75\%-100\%) dengan persentase implementasi sebesar $82,50 \%$.

Hasil penilaian pelaksanaan pembelajaran menunjukkan bahwa implementasi Kurikulum 2013 sepenuhnya terlaksana, akan tetapi masih terdapat kelemahan yang menyebabkan tingkat implementasi Kurikulum 2013 tidak maksimal yaitu pada butir sub indikator (1) Penggunakan pendekatan project based learning dalam pelaksanakan kegiatan pembelajaran. Kurang optimalnya nilai implementasi pada sub indikator menandakan bahwa guru belum menerapkan pendekatan problem base learning pada semua kegiatan pembelajaran. Hal tersebut juga telah dikonfirmasi oleh guru bahwa dalam pembelajaran, tidak semua kompetensi bisa menggunakan pendekatan tersebut, project based learning masih diterapkan pada kompetensi yang memungkinkan untuk diterapkannya pendekatan tersebut. (2) Penyimpulkan materi pembelajaran yang telah disampaikan bersama siswa. Kurang optimalnya nilai implementasi pada hal tersebut menandakan bahwa setiap akhir kegiatan pembelajaran, guru tidak selalu dalam setiap pembelajaran melibatkan siswa dalam menyimpulkan materi pelajaran. (3) Pemberian informasi kepada siswa tentang materi pembelajaran yang akan disampaikan pada pertemuan berikutnya. Kurang optimalnya nilai implementasi pada hal tersebut menandakan bahwa setiap akhir kegiatan pembelajaran, guru tidak selalu menyampaikan materi pembelajaran pada pertemuan selanjutnya. 
Penilaian aspek pelaksanaan pembelajaran bagian ini, merupakan gambaran pelaksanaan pembelajaran dilihat dari segi siswa selaku sasaran dalam pelaksanaan pembelajaran yang mengacu Kurikulum 2013. Hasil penilaian menunjukkan bahwa: (1) Implementasi Kurikulum 2013 oleh guru dalam kegiatan pendahuluan masuk dalam kategori sepenuhnya terlaksana (75\%-100\%) dengan presentase sebesar 92,28\%. (2) Implementasi Kurikulum 2013 dalam kegiatan inti masuk dalam kategori sepenuhnya terlaksana $(75 \%$ 100\%) dengan presentase sebesar 87,73\%. (3) Implementasi Kurikulum 2013 dalam kegiatan penutup masuk dalam kategori sepenuhnya terlaksana (75\%-100\%) dengan presentase sebesar $85,33 \%$. Hasil penilaian pelaksanaan pembelajaran praktik PSPTKR oleh siswa dapat dilihat pada Tabel 5 berikut:

Tabel 5. Hasil Penilaian Aspek Pelaksanaan Pembelajaran oleh Siswa.

\begin{tabular}{|c|c|c|}
\hline Indikator & Persentase & Kriteria \\
\hline $\begin{array}{c}\text { Kegiatan } \\
\text { Pedahuluan }\end{array}$ & $92,28 \%$ & $\begin{array}{c}\text { Sepenuhnya } \\
\text { Terlaksana }\end{array}$ \\
\hline Kegiatan Inti & $87,73 \%$ & $\begin{array}{c}\text { Sepenuhnya } \\
\text { Terlaksana }\end{array}$ \\
\hline $\begin{array}{c}\text { Kegiatan } \\
\text { Penutup }\end{array}$ & $85,33 \%$ & $\begin{array}{c}\text { Sepenuhnya } \\
\text { Terlaksana }\end{array}$ \\
\hline $\begin{array}{c}\text { Rata-rata } \\
\text { Persentase }\end{array}$ & $\mathbf{8 5 , 4 5 \%}$ & $\begin{array}{c}\text { Sepenuhnya } \\
\text { Terlaksana }\end{array}$ \\
\hline
\end{tabular}

Hasil penilaian pada aspek pelaksanaan pembelajaran oleh siswa, apabila disajikan dalam grafik dapat dilihat pada gambar 3 berikut:

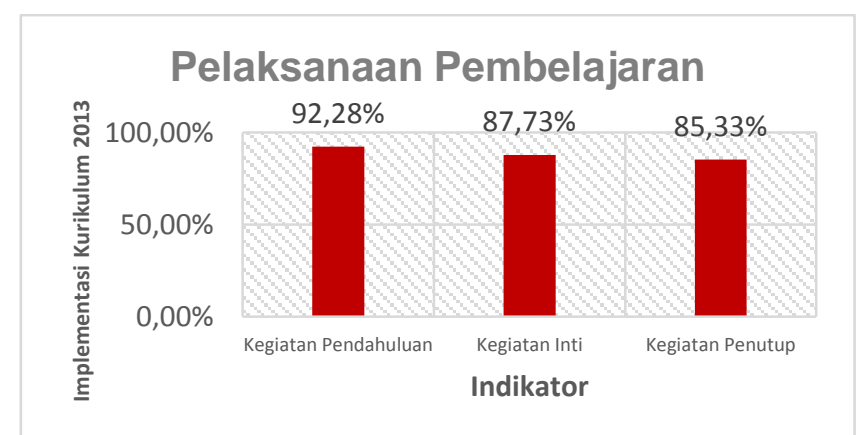

Gambar 3. Diagram batang hasil penilaian implementasi Kurikulum 2013 dalam pelaksanaan pembelajaran praktik PSPTKR oleh siswa.

Hasil penilaian pelaksanaan pembelajaran oleh siswa menunjukkan implementasi Kurikulum 2013 sepenuhnya terlaksana, akan tetapi masih terdapat kelemahan yang menyebabkan tingkat implementasi Kurikulum 2013 tidak maksimal yaitu guru belum intensif melakukan refleksi atau membuat rangkuman dengan melibatkan peserta didik pada kegiatan penutup pembelajaran.

Penilaian pembelajaran merupakan upaya untuk mengetahui penguasaan materi dan kompetensi yang dicapai oleh siswa. Pengambilan data dalam penilaian pembelajaran ini 
melibatkan guru pengampu pembelajaran praktik PSPTKR. Hasil yang diperoleh dari pengambilan data mengenai penilaian pembelajaran dapat dilihat pada Tabel 6 berikut:

Tabel 6. Hasil Penilaian Aspek Penilaian Pembelajaran oleh Guru

\begin{tabular}{|c|c|c|}
\hline Indikator & Persentase & Kriteria \\
\hline $\begin{array}{c}\text { Penilaian Hasil } \\
\text { Belajar Siswa }\end{array}$ & $82,08 \%$ & $\begin{array}{c}\text { Sepenuhnya } \\
\text { Terlaksana }\end{array}$ \\
\hline $\begin{array}{c}\text { Pelaporan Hasil } \\
\text { Penilaian }\end{array}$ & $77,50 \%$ & $\begin{array}{c}\text { Sepenuhnya } \\
\text { Terlaksana }\end{array}$ \\
\hline $\begin{array}{c}\text { Rata-rata } \\
\text { Persentase }\end{array}$ & $\mathbf{8 1 , 4 3 \%}$ & $\begin{array}{c}\text { Sepenuhnya } \\
\text { Terlaksana }\end{array}$ \\
\hline
\end{tabular}

Hasil penilaian pada aspek penilaian pembelajaran, apabila disajikan dalam grafik dapat dilihat pada gambar 4 berikut:

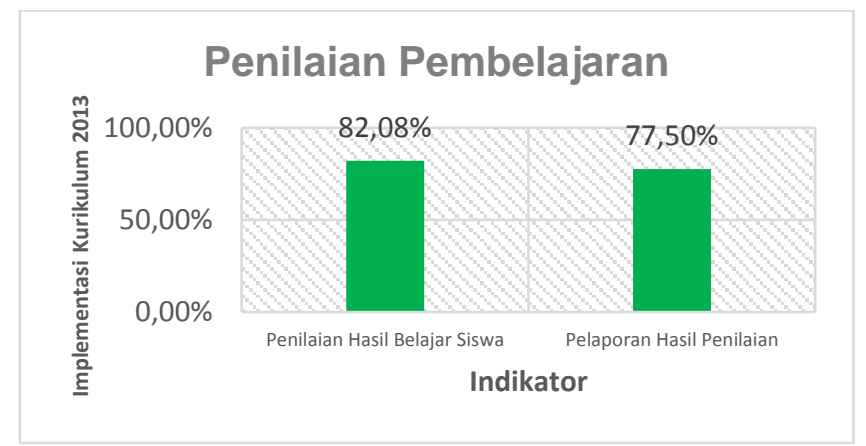

Gambar 4. Diagram batang hasil penilaian implementasi Kurikulum 2013 dalam penilaian pembelajaran praktik PSPTKR oleh guru.

Hasil penilaian pelaksanaan pembelajaran oleh guru menunjukkan bahwa (1) Implementasi Kurikulum 2013 dalam kegiatan penilaian hasil belajar siswa yang dilaksanakan oleh guru masuk dalam kriteria sepenuhnya terlaksana (75\%-100\%) dengan persentase implementasi sebesar 81,43\%. (2) Implementasi Kurikulum 2013 dalam kegiatan pelaporan hasil penilaian siswa yang dilaksanakan oleh guru masuk dalam kriteria sepenuhnya terlaksana (75\%-100\%) dengan persentase implementasi sebesar 77,50 \%.

Hasil penilaian perencanaan pembelajaran menunjukkan implementasi Kurikulum 2013 sepenuhnya terlaksana, akan tetapi masih terdapat kelemahan yang menyebabkan tingkat implementasi Kurikulum 2013 tidak maksimal yaitu (1) belum maksimalnya pelaksanaan penilaian projek yang meliputi kegiatan perancangan, pelaksanaan, dan pelaporan secara tertulis maupun lisan. 2) belum maksimalnya pelaksanaan penilaian ulangan tengah semester untuk mengukur seluruh indikator pencapaian kompetensi siswa yang merepresentasikan seluruh KD pada periode tersebut. (3) belum maksimalnya pelaksanaan tes lisan untuk mengukur seluruh indikator pencapaian kompetensi siswa yang merepresentasikan seluruh indikator pencapain kompetensi siswa. (4) belum maksimalnya pelaksanaan penilaian observasi dengan menggunakan pedoman yang berisi sejumlah indikator perilaku siswa yang akan diamati. 


\section{SIMPULAN DAN SARAN}

\section{Simpulan}

Implementasi kurikukulum 2013 dalam perencanaan pembelajaran praktik PSPTKR di SMK Muhammadiyah 1 Bantul, masuk dalam kategori sepenuhnya terlaksana dengan persentase implementasi sebesar $86,35 \%$. Namun demikian, masih terdapat ketidakoptimalan dalam implementasi perencanaan pembelajaran dikarenakan guru masih belum maksimal dalam menerapkan prinsip-prinsip dalam penyusunan RPP, di samping itu guru belum menentukan buku pokok yang menjadi acuan bagi siswa. Implementasi kurikukulum 2013 dalam pelaksanaan pembelajaran praktik PSPTKR di SMK Muhammadiyah 1 Bantul, masuk dalam kategori sepenuhnya terlaksana dengan persentase implementasi sebesar $86,92 \%$. Namun demikian, dalam pelaksanaan pembelajaran masih terdapat ketidakoptimalan implementasi Kurikulum 2013 yaitu guru cenderung masih kurang memiliki sikap positif dalam berinteraksi dengan siswa dan belum maksimal dalam mendukung partisipasi aktif siswa.Implementasi kurikukulum 2013 dalam penilaian pembelajaran praktik PSPTKR di SMK Muhammadiyah 1 Bantul, masuk dalam kategori sepenuhnya terlaksana dengan persentase implementasi sebesar $81,43 \%$. Namun demikian, masih terdapat ketidakoptimalan dalam implementasi penilaian pembelajaran dikarenakan guru belum optimal dalam menggunakan variasi metode penilaian untuk mengukur kompetensi siswa.

\section{Saran}

Berdasarkan hasil penelitian yang diperoleh, ada beberapa pandangan peneliti yang sekiranya dapat dijadikan sebagai saran bagi pihak-pihak yang bersangkutan, yaitu: (1) Bagi pihak sekolah perlu menyediakan buku ajar yang berbasis Kurikulum 2013 agar dapat digunakan sebagai referensi siswa selama pembelajaran berlangsung, sehingga sumber belajar siswa seragam dan baku. (2) Bagi guru perlu meningkatkan kreativitas dalam menggunakan metode pembelajaran yang lebih menarik dan variatif, sehingga siswa lebih termotivasi dan lebih aktif dalam mengikuti kegiatan pembelajaran. Begitu pula dengan perencanaan pembelajaran yang perlu disusun dengan memperhatikan tingkat intelektual siswa, potensi siswa, gaya belajar siswa, kecepatan belajar siswa, perkembangan inspirasi, motivasi, kreativitas, dan minat siswa. Kemudian guru juga perlu melibatkan siswa lebih banyak dalam pembelajaran, meningkatkan respon positif, dan menunjukkan sikap terbuka terhadap keaktifan siswa, dengan begitu tujuan dari Kurikulum 2013 lebih bisa tercapai. Selain itu, acuan yang dijadikan sumber belajar alangkah baiknya apabila mengambil sumber terbaru, mengingat bahwa perkembangan dalam teknologi kendaraan sangat pesat. Selanjutnya, dalam penilaian pembelajaran guru sebaiknya menggunakan metode penilaian yang lebih bervariasi selain tes praktik yaitu tes tulis dan tes lisan.

\section{DAFTAR PUSTAKA}

Arikunto, Suharsimi. (2013). Prosedur Penelitian Suatu Pendekatan Praktek. Jakarta: PT Rineka Cipta

As'ari, Abdur Rahman. (Maret 2014). Perspektif Global Tentang Kurikulum 2013 Secara Umum, dan Pembelajaran Matematika Secara Khusus. Makalah disajikan dalam Seminar Internasional K-13 Implementation from Global Perspective, di UM Ponorogo. 
Daryanto. (2014). Pendekatan Pembelajaran Saintifik Kurikulum 2013. Yogyakarta: Gava Media.

Riduan. (2013). Belajar Mudah Penelitian Untuk Guru, Karyawan dan Peneliti Pemula. Bandung: Alfabeta

Siswoyo, Dwi. (2013). Ilmu Pendidikan. Yogyakarta: UNY Press.

Sofyan, H., Arifin, Z., \& Tafakur. (2017). The implementation of scientific learning at automotive engineering study program on vocational high school. Prosiding dan Konferensi Internasional tentang Guru Teknologi dan Kejuruan (ICTVT 2017) yang diselenggarakan oleh FT UNY, bulan September 2017. Yogyakarta: Universitas Negeri Yogyakarta.

Sukmadinata, Nana Syaodih. (2013). Metode Penelitian Pendidikan. Bandung: PT Remaja Rosdakarya.

Yuswono, L. C., Martubi, Sukaswanto, \& Budiman, A. (2015). Profil Kompetensi Guru SMK Teknik Kendaraan Ringan di Daerah Istimewa Yogyakarta. Penelitianpendidikan, 438. 